\title{
LGALS3 Antibody
}

National Cancer Institute

\section{Source}

National Cancer Institute. LGALS3 Antibody. NCI Thesaurus. Code C121502.

Any immunog lobulin that recognizes galectin-3. 